ISTIGHNA, Vol. 3, No 1, Januari 2020 P-ISSN 1979-2824 E-ISSN 2655-8459

Homepage: http://e-journal.stit-islamic-village.ac.id/index.php/istighna

Nurhasimah, Nunu Mahnun, Rini Setyaningsih

Penyusunan Rencana Kerja Madrasah Di Madrasah Aliyah Negeri 1 Pekanbaru

\title{
PENYUSUNAN RENCANA KERJA MADRASAH DI MADRASAH ALIYAH NEGERI 1 PEKANBARU
}

\author{
Nurhasimah \\ nurhasimahkarla18@gmail.com \\ Universitas Islam Negeri Sultan Syarif Kasim Riau \\ Nunu Mahnun \\ nunu.mahnun@uin-suska.ac.id \\ Universitas Islam Negeri Sultan Syarif Kasim Riau \\ Rini Setyaningsih \\ rinisetyaningsih28@gmail.com \\ Universitas Islam Negeri Sultan Syarif Kasim Riau
}

\begin{abstract}
The aim of this research was to investigate the arrangement of madrasa work plan in Madrasah Aliyah 1 Pekanbaru. The type of this research was descriptive qualitative research, the subject of this research was the headmaster, the head of administration, the vice headmaster of the curriculum, the student affairs, and facilities and infrastucture. The object of the research was the arrangement of madrasa work plan in Madrasah Aliyah 1 Pekanbaru. The techniques used in collecting data were interview and documentation. The analysis method used transcribing, coding, categorizing, and interpreting data. The research finding was the headmaster had designed the madrasa work plan by 1) Forming work plan by involving the head of administration, the vice headmasters, and school committee; 2) Giving direction about arranging madrasa work plan such as basics of arrangement, objectives, and budget needed in arranging madrasa work plan; 3) Arranging plan of activities such as decription of activities, implementation, and expected results; 4) Arranging draft of RKJM by identifying real challenge and making work program; 5) reviewing and revising draft of RKJM; 6) Finalizing revision result of RKJM by executing the approval; 7) Signing the result of RKJM as Madrasa Strategic Plan; 8) arranging draft of RKT; 9) Reviewing and revising draft of RKT; and 10) Finalizing revision result of $R K T$ by executing the approval. 11)Signing the result finalization of RKT as Madrasa Annual Activity Plan and and Budget.
\end{abstract}

\section{Keywords: Madrasa, work plan, systematic}

Abstrak: Tujuan dari penelitian ini adalah untuk mengetahui bagaimana Sistematika Penyusunan Rencana Kerja Madrasah di Madrasah Aliyah Negeri 1 Pekanbaru. Jenis penelitian ini adalah penelitian deskriptif kualitatif, subjek penelitian ini adalah Kepala Madrasah, Kepala Tata Usaha, Waka Kurikulum, Waka Kesiswaan dan Waka Sarana dan Prasarana, sedangkan objek penelitian ini adalah Sistematika Penyusunan Rencana Kerja Madrasah di Madrasah Aliyah Negeri 1 Pekanbaru. Teknik yang digunakan dalam pengumpulan data penelitian menggunakan teknik wawancara dan dokumentasi. Metode analisis data dengan

Peer reviewed under reponsibility of STIT ISLAMIC VILLAGE.

(C) 2018 STIT ISLAMIC VILLAGE, All right reserved, This is an open access article under 1 the CC BY SA license (https://creativecommons.org/licenses/by-sa/4.0/) 
ISTIGHNA, Vol. 3, No 1, Januari 2020 P-ISSN 1979-2824 E-ISSN 2655-8459

Homepage: http://e-journal.stit-islamic-village.ac.id/index.php/istighna

Nurhasimah, Nunu Mahnun, Rini Setyaningsih

Penyusunan Rencana Kerja Madrasah Di Madrasah Aliyah Negeri 1 Pekanbaru

menggunakan transkripsi, pengkodean dan kategorisasi, dan interpretasi data. Adapun hasil dari penelitian ini adalah Kepala Madrasah menyusun Rencana Kerja Madrasah tersebut dengan cara: 1. Pembentukan tim kerja dengan melibatkan Kepala Tata Usaha, Wakil Kepala Madrasah dan Komite Madrasah. 2. Memberikan arahan tentang penyusunan Rencana Kerja Madrasah seperti dasar-dasar penyusunan, tujuan dan anggaran yang dibutuhkan dalam penyusunan rencana kerja madrasah. 3. Menyusun rencana kegiatan seperti uraian kegiatan yang akan dilaksanakan, pelaksananya, dan juga hasil yang diharapkan. 4. Menyusun draf Rencana Kerja Jangka Menengah dengan mengidentifikasi tantangan nyata dan membuat program kerja. 5. Review dan revisi draf Rencana Kerja Jangka Menengah. 6.Finalisasi hasil revisi Rencana Kerja Jangka Menengah. 7. Penandatanganan hasil finalisasi Rencana Kerja Jangka Menengah menjadi rencana strategis Madrasah 8. Menyusun draf Rencana Kerja Tahunan.9. Review dan revisi draf Rencana Kerja Tahunan. 10. Finalisasi hasil revisi Rencana Kerja Tahunan.11. Penandatanganan hasil finalisasi Rencana Kerja Tahunan menjadi Rencana Kegiatan dan Anggaran Madrasah.

\section{Kata Kunci: Madrasah, rencana kerja, sitematika}

\section{A. PENDAHULUAN}

Setiap kegiatan pada satuan pendidikan dikelola atas dasar Rencana Kerja Madrasah (RKM). RKM adalah dokumen yang sangat penting yang harus ada di setiap madrasah karena dokumen tersebut dapat menjamin keberlangsungan proses pendidikan di suatu madrasah. Salah satu isi dari Standar Nasional Pendidikan adalah bahwa setiap satuan pendidikan wajib mempunyai Rencana Kerja Sekolah/Madrasah yang akan dilaksanakan dalam jangka waktu empat tahun. Dalam menyusun Rencana Kerja Madrasah hendaknya dilakukan secara bertahap dengan melibatkan banyak pihak seperti Kepala Madrasah, guru dan Komite Madrasah. ${ }^{1}$

RKM merupakan rencana yang komprehensif untuk mengoptimalkan pemanfaatan segala sumber daya yang ada dan yang mungkin diperoleh guna mencapai tujuan yang diinginkan di masa mendatang. RKM harus berorientasi ke depan dan secara jelas bagaimana menjembatani antara kondisi saat ini dan harapan yang ingin dicapai di masa depan. RKM juga harus memperhatikan peluang dan ancaman dari lingkungan eksternal, memerhatikan kekuatan dan kelemahan internal, dan kemudian mencari dan menemukan strategi dan program-program untuk memanfaatkan peluang dan kekuatan yang dimiliki,

${ }^{1}$ Sokhibi, Peningkatan Kemampuan Kepala Madrasah dalam Menyusun Rencana Kerja Madrasah melalui Workshop KKMI Kecamatan Adiwerna, Jurnal Pendidikan, Vol. 8, No. 1, Maret 2018, h. 116-117 
ISTIGHNA, Vol. 3, No 1, Januari 2020 P-ISSN 1979-2824 E-ISSN 2655-8459

Homepage: http://e-journal.stit-islamic-village.ac.id/index.php/istighna

Nurhasimah, Nunu Mahnun, Rini Setyaningsih

Penyusunan Rencana Kerja Madrasah Di Madrasah Aliyah Negeri 1 Pekanbaru

mengatasi tantangan dan kelemahan yang ada, guna mencapai visi yang diinginkan. $^{2}$

Setiap Madrasah harus merumuskan visi Madrasah sebagai cita-cita bersama warga Madrasah dan segenap pihak yang berkepentingan pada masa yang akan datang; mampu memberikan inspirasi, motivasi, dan kekuatan pada warga Madrasah dan segenap pihak yang berkepentingan; dirumuskan berdasar masukan dari berbagai warga Madrasah dan pihak-pihak yang berkepentingan, selaras dengan visi institusi di atasnya, serta visi pendidikan nasional; diputuskan dalam rapat dewan pendidik yang dipimpin oleh Kepala Madrasah dengan memerhatikan masukan Komite Madrasah; disosialisasikan kepada warga Madrasah dan seganap pihak yang berkepentingan; serta ditinjau dan dirumuskan kembali secara berkala sesuai dengan perkembangan dan tantangan di masyarakat. ${ }^{3}$

Kebutuhan Madrasah dan aspirasi masyarakat menjadi dasar utama penyusunan RKM. Dengan kata lain, RKM bertujuan untuk mengemukakan apa yang diperlukan madrasah serta harapan masyarakat di sekitar Madrasah. Dengan adanya RKM yang jelas, semua pihak yang berkepentingan - orang tua, guru, pegawai Madrasah, Komite Madrasah, warga di sekitar Madrasah dan Kepala Madrasah sendiri akan mengetahui: apa yang dibutuhkan oleh Madrasah, apa yang perlu dilakukan untuk memperbaiki keadaan Madrasah, maksud dan tujuan kegiatan yang akan dilakukan selama beberapa tahun yang akan datang. ${ }^{4}$

Dalam Juknis Penyusunan Rencana Kerja Sekolah, disebutkan bahwa sekolah pada umumnya telah memiliki visi, misi dan tujuan sekolah, akan tetapi masih banyak sekolah yang belum memiliki dokumen Rencana Kerja Sekolah sesuai rambu-rambu yang ada. Selain itu, ada juga sekolah yang telah menyusun program kerja tahunan, namun masih terdapat sekolah yang belum menyusun rencana program empat tahunan, dan juga belum semua sekolah menyusun program kerja secara komprehensif dalam rangka pencapaian SNP. Salah satu kendalanya adalah karena dalam penyusunan program kerja tidak didukung dengan hasil analisis konteks yang mencakup analisis delapan SNP, analisis satuan pendidikan dan analisis lingkungan satuan pendidikan. ${ }^{5}$

Secara umum, Madrasah Aliyah Negeri 1 Pekanbaru sudah menyusun Rencana Kerja Madrasah (RKM) yang terdiri dari Rencana Kerja Jangka Menengah (RKJM) dan Rencana Kerja Tahunan (RKT) / Rencana Kerja dan

\footnotetext{
${ }^{2}$ Muhaimin, dkk., Manajemen Pendidikan (Aplikasinya dalam Penyusunan Rencana Pengembangan Sekolah/Madrasah, Jakarta: Kencana Prenada Media Group, 2011, h.199-200

${ }^{3}$ Ridwan Abdullah Sani, dkk., Penjaminan Mutu Sekolah, Jakarta: PT Bumi Aksara, 2015, h. 101-102

${ }^{4}$ Muhaimin, dkk.,Op.Cit., h.200

${ }^{5}$ Direktorat,Juknis Penyusunan Rencana Kerja SMA, 2010, h.11
} 
ISTIGHNA, Vol. 3, No 1, Januari 2020 P-ISSN 1979-2824 E-ISSN 2655-8459

Homepage: http://e-journal.stit-islamic-village.ac.id/index.php/istighna

Nurhasimah, Nunu Mahnun, Rini Setyaningsih

Penyusunan Rencana Kerja Madrasah Di Madrasah Aliyah Negeri 1 Pekanbaru

Anggaran Madrasah (RKAM).Rencana Kerja Madrasah itu sendiri akan menjadi tolak ukur pertanggungjawaban pada setiap akhir tahun anggaran Madarasah Aliyah Negeri 1 Pekanbaru kepada stakeholder.Selain itu Madrasah Aliyah Negeri 1 Pekanbaru merupakan Madrasah yang telah terakreditasi A. Salah satu program unggulan yang terdapat pada MAN 1 Pekanbaru yaitu program Smart Class (SC) yang dimulai dari tahun ajaran 2017/2018. Program ini bertujuan untuk menunjang para siswa dan siswi yang telah tergabung untuk dapat meraih prestasi diberbagai kompetisi akademik. Beberapa prestasi yang diraih oleh siswa dan siswi MAN 1 Pekanbaru diantaranya yaitu: Juara 1 Mechanical Drawing Politeknik Caltek Riau Juli 2018, Juara 1 Line Follower Competition Politeknik Caltek Riau, Juara 3 LKTI Nasional UII Jogjakarta Agustus 2018, Medali Perak KSM Bidang Fisika Tingkat Nasional 2018, Terbaik Rayon Olimpiade Matematika Universitas Brawijaya Malang, Medali Perak Kebumian Science Competition Expo USU Medan, Juara 2 Syaria Economic Olympiade Unair Surabaya dan masih banyak lagi prestasi lainnya.

Berdasarkan studi pendahuluan yang dilakukan oleh peneliti di lokasi penelitian di Madrasah Aliyah Negeri 1 Pekanbaru pada tanggal 7 September 2018, makapeneliti menemukan gejala-gejala sebagai berikut:

1. Madrasah Aliyah Negeri 1 Pekanbaru sudah melakukan penyusunan Rencana Kerja Madrasah yang terdiri dari Rencana Kerja Jangka Menengah dan Rencana Kerja Tahunan.

2. Dalam Penyusunan Rencana Kerja Madrasah sudah melibatkan semua pihak, seperti Kepala Madrasah, Wakil Kepala Madrasah, guru-guru dan Komite Madrasah.

3. Tim penyusun Rencana Kerja Madrasah sudah memahami cara penyusunan Rencana Kerja Madrasah.

4. Masih ada program kerja Madrasah yang belum terealisasi dengan baik.

\section{B. LANDASAN TEORI}

Penyusunan adalah proses, cara, perbuatan menyusun. ${ }^{6}$ Penyusunan berasal dari kata dasar susun. Penyusunan memiliki arti dalam kelas nomina atau kata benda sehingga penyusunan dapat menyatakan nama dari seseorang, tempat, atau semua benda dan segala yang dibendakan. RKM merupakan rencana yang komprehensif untuk mengoptimalkan pemanfaatan segala sumber daya yang ada dan yang mungkin diperoleh guna mencapai tujuan yang diinginkan di masa mendatang. RKM harus berorientasi ke depan dan secara jelas bagaimana menjembatani antara kondisi saat ini dan harapan yang ingin dicapai di masa depan. RKM juga harus memperhatikan peluang dan ancaman

${ }^{6}$ Kementerian Pendidikan dan Kebudayaan Republik Indonesia, Badan Pengembangan dan Pembinaan Bahasa, 2016. 
ISTIGHNA, Vol. 3, No 1, Januari 2020 P-ISSN 1979-2824 E-ISSN 2655-8459

Homepage: http://e-journal.stit-islamic-village.ac.id/index.php/istighna

Nurhasimah, Nunu Mahnun, Rini Setyaningsih

Penyusunan Rencana Kerja Madrasah Di Madrasah Aliyah Negeri 1 Pekanbaru

dari lingkungan eksternal, memerhatikan kekuatan dan kelemahan internal, dan kemudian mencari dan menemukan strategi dan program-program untuk memanfaatkan peluang dan kekuatan yang dimiliki, mengatasi tantangan dan kelemahan yang ada, guna mencapai visi yang diinginkan. ${ }^{7}$

Rencana kerja Madrasah terdiri atas Rencana Kerja Jangka Menengah dan Rencana Kerja Tahunan. Rencana Kerja Madrasahdituangkan dalam dokumen yang mudah dibaca oleh pihak-pihak yang terkait. Rencana Kerja Jangka Menengah menggambarkan tujuan yang akan dicapai dalam kurun waktu empat tahun yang berkaitan dengan mutu lulusan yangingin dicapai dan perbaikan komponen yang mendukung peningkatan mutu lulusan. Sedangkan Rencana Kerja Tahunan adalah Rencana Kerja Tahunan Madrasah yang berdasar pada Rencana Kerja Jangka Menengah (empat tahunan) yang dinyatakan dalam Rencana Kegiatan dan Anggaran Madrasah (RKAM) sebagai istilah lain dari Rencana Anggaran Penerimaan dan Belanja Madrasah $\left(\right.$ RAPB-M). ${ }^{8}$

Rencana Kerja Tahunan memuat ketentuan yang jelas mengenai:

a. Kesiswaan

b. Kurikulum dan kegiatan pembelajaran

c. Pendidik dan tenaga kependidikan serta pengembangannya

d. Sarana dan prasarana

e. Keuangan dan pembiayaan

f. Budaya dan lingkungan sekolah

g. Peran serta masyarakat dan kemitraan, dan

h. Rencana-rencana kerja lain yang mengarah kepada peningkatan dan pengembangan mutu pendidikan. ${ }^{9}$

\section{Tujuan, Karakteristik, dan Mnafaat dari Rencana Kerja Madrasah}

Terintegrasi, Multitahun, Setiap tahun diperbarui, Multisumber, Partisipatif, Dimonitor ${ }^{10}$. Tujuan dari Rencana Kerja Madrasah disusun dengan tujuan untuk:

a. Menjamin agar perubahan/tujuan Madrasah yang ditetapkan dapat dicapai dengan tingkat kepastian yang tinggi dan resiko yang kecil

b. Mendukung koordinasi antarpelaku Madrasah.

c. Menjamin terciptanya integrasi, sinkronisasi, dan sinergi baik antar pelaku Madrasah atau antara Madrasah dengan Departemen Agama.

\footnotetext{
${ }^{7}$ Muhaimin, dkk., Loc.Cit., h.199-200

${ }^{8}$ Direktorat,Juknis Penyusunan Rencana Kerja SMA,Op.Cit., h.13

${ }^{9}$ Suparlan, Manajemen Berbasis Sekolah dari Teori Sampai dengan Praktik, Jakarta: PT Bumi Aksara, 2013, h. 65-66

${ }^{10}$ Muhaimin, dkk., Op.Cit., h.200
} 
ISTIGHNA, Vol. 3, No 1, Januari 2020 P-ISSN 1979-2824 E-ISSN 2655-8459

Homepage: http://e-journal.stit-islamic-village.ac.id/index.php/istighna

Nurhasimah, Nunu Mahnun, Rini Setyaningsih

Penyusunan Rencana Kerja Madrasah Di Madrasah Aliyah Negeri 1 Pekanbaru

d. Menjamin keterkaitan antara perencanaan, penganggaran, pelaksanaan, dan pengawasan.

e. Mengoptimalkan partisipasi warga Madrasah dan masyarakat.

f. Menjamin tercapainya pengguanaan sumber daya secara efisien, efektif, berkeadilan, dan berkelanjutan.

Manfaat dari Rencana Kerja Madrasah bermanfaat untuk dijadikan sebagai:

a. Pedoman kerja (kerangka acuan) dalam pengembangan Madrasah.

Sarana untuk melakukan monitoring dan evaluasi pelaksanaan pengembangan Madrasah.

b. Bahan acuan untuk mengidentifikasi dan mengajukan sumber daya pendidikan yang diperlukan. $^{11}$

\section{Landasan Hukum Rencana Kerja Madrasah}

Penyusunan Rencana Kerja Madrasah merupakan kegiatan yang wajib dilakukan oleh Madrasah. Penyusunan Rencana Kerja Madrasah dilandasi oleh undang-undang dan berbagai peraturan-peraturan dari pemerintah. Berikut merupakan beberapa landasan hukum yang digunakan dalam penyusunan Rencana Kerja Madrasah:

a. Undang-Undang Nomor 20 Tahun 2003 tentang Sistem Pendidikan Nasional, Pasal 51 ayat 1.

b. Peraturan Pemerintah Nomor 19 Tahun 2005 tentang Standar Nasional Pendidikan, Pasal 53 ayat 1.

c. Peraturan Pemerintah Nomor 17 Tahun 2010 tentang Pengelolaan dan Penyelenggaraan Pendidikan, Pasal 51.

d. Peraturan Menteri Pendidikan Nasional RI Nomor 19 Tahun 2007 tentang Standar Pengelolaan Pendidikan.

e. Peraturan Pemerintah Nomor 48 Tahun 2008 tentang Pendanaan Pendidikan.

\section{METODE PENELITIAN}

Jenis penelitian ini adalah penelitian deskriptif kualitatif, subjek penelitian ini adalah Kepala Madrasah, Kepala Tata Usaha, Waka Kurikulum, Waka Kesiswaan dan Waka Sarana dan Prasarana, sedangkan objek penelitian ini adalah Sistematika Penyusunan Rencana Kerja Madrasah di Madrasah Aliyah Negeri 1 Pekanbaru. Teknik yang digunakan dalam pengumpulan data penelitian menggunakan teknik wawancara dan

${ }^{11}$ Muhaimin, dkk., Op.Cit., h.201 
ISTIGHNA, Vol. 3, No 1, Januari 2020 P-ISSN 1979-2824 E-ISSN 2655-8459

Homepage: http://e-journal.stit-islamic-village.ac.id/index.php/istighna

Nurhasimah, Nunu Mahnun, Rini Setyaningsih

Penyusunan Rencana Kerja Madrasah Di Madrasah Aliyah Negeri 1 Pekanbaru

dokumentasi. Metode analisis data dengan menggunakan transkripsi, pengkodean dan kategorisasi, dan interpretasi data.

\section{HASIL PENELITIAN}

Sistematika Penyususnan Rencana Kerja Madrasah Aliyah Negeri 1 Pekanbaru.

1. Pembentukan Tim Panitia

Kepala Madrasah Negeri 1 Pekanbaru membentuk tim kerja dengan melibatkan Kepala Tata Usaha dan Wakil Kepala yang terdiri dari Waka Kurikulum, Waka Kesiswaan, Waka Sarana-Prasarana, Waka Humas, Waka Keislaman dan Komite Madrasah dalam kegiatan penyusunan rencana kerja madrasah dengan dibuatkan SK untuk setiap orang yang terlibat dan setelah itu dibentuk tim kerja dari masing-masing bidang.

2. Pemberian Arahan

Sebelum melakukan penyusunan rencana kerja, Kepala MAN 1 Pekanbaru memberikan arahan teknis kepada tim yang sudah dibentuk. Arahan yang diberikan oleh Kepala MAN 1 Pekanbaru yaitu tentang strategi untuk membuat rencana kerja madrasah. Seperti dasar-dasar penyusunannya, tujuan dari penyusunannya dan juga anggaran yang dibutuhkan untuk penyusunan rencana kerja madrasah.

3. Penyusunan Rencana Kegiatan Tim

Setiap tim kerja panitia harus menyusun rencana kegiatan untuk penyusunan rencana kerja madrasah. Dimana rencana kegiatan itu memuat tentang uraian kegiatan yang akan dilaksanakan, anggaran yang diperlukan, pelaksananya, dan juga hasil yang diharapkan seperti apa. Namun sebelum itu harus dilakukan evaluasi terhadap kegiatan yang sudah dilaksanakan sehingga diketahui apa saja kekurangan dan kelebihan dari kegiatan tersebut.

Masing-masing bidang dari Tim, membuat rencana kerja dan setelah itu dirumuskan bersama dengan Kepala Madrasah, disempurnakan dan disampaikan dengan Komite Madrasah. Dalam menyusun rencana kegiatan penyusunan Rencana kegiatan berisi uraian kegiatan, sasaran/hasil, pelaksana, dan jadwal pelaksanaan. Rencana kegiatan juga memuat tentang uraian kegiatan yang akan dilaksanakan, anggaran yang diperlukan, pelaksanaan, dan juga hasil yang diharapkan.

4. Penyusunan Draf RKJM

Langkah selanjutnya yang dilakukan oleh tim kerja untuk menyusun draf RKJM adalah; yang pertama setiap bidang merumuskan apa saja langkah yang akan dilakukan terkait dengan kegiatan-kegiatan yang akan 
ISTIGHNA, Vol. 3, No 1, Januari 2020 P-ISSN 1979-2824 E-ISSN 2655-8459

Homepage: http://e-journal.stit-islamic-village.ac.id/index.php/istighna

Nurhasimah, Nunu Mahnun, Rini Setyaningsih

Penyusunan Rencana Kerja Madrasah Di Madrasah Aliyah Negeri 1 Pekanbaru

dilaksanakan untuk tahun berikutnya. Dan penyusunannya mengikuti pedoman yang ada seperti mengidentifikasi tantangan nyata, membuat kegiatan atau program kerja, dan juga melakukan evaluasi. Setelah itu baru disusun lagi bersama Kepala Madrasah dan bidang-bidang yang lain.

Tim kerja Madrasah mengumpulkan, mengolah data dan informasi dan menyusun draf Rencana Kerja Jangka Menengah (RKJM), yang mencakup: Pendahuluan, dasar kebijakan, identifikasi tantangan nyata berdasarkan analisis konteks, analisis kondisi, program strategis, strategi pencapaian, monitoring dan evaluasi, lampiran-lampiran.

5. Review dan Revisi Draf

Langkah selanjutnya yang dilakukan oleh tim kerja setelah melakukan penysunan draf RKJM, dilakukan review dan revisi lagi. Karena tidak semua kegiatan yang dibuat oleh masing-masing bidang itu disetujui oleh Kepala MAN 1 Pekanbaru. Dan waktu yang dibutuhkan untuk mereview dan merevisi draf RKJM tersebut tidak sampai satu minggu, karena untuk penyusunan rencana kerja madrasah tersebut diberi waktu maksimal satu bulan dan itu sudah mencakup dari pembentukan tim sampai dengan finalisasi.

6. Finalisasi Hasil Revisi Draf RKJM

Hal-hal yang dilakukan oleh Kepala MAN 1 Pekanbaru dan tim kerja pada saat finalisasi hasil revisi RKJM ini adalah Kepala Madrasah berkumpul bersama Wakil Kepala membahas kegiatan yang sudah dirumuskan dan dilakukan pengesahan.

\section{Penyusunan Draf RKT}

Aspek yang dilihat oleh Kepala MAN 1 Pekanbaru dan tim kerja dalam menyusun draf RKT yaitu dari kebutuhan masyarakat. Dimana masyarakat menilai suatu madrasah tersebut berkualitas atau tidak ialah dari prestasi yang diraih. Jadi yang aspek yang lebih dominan dilihat disini adalah dibagian akademik.

8. Review dan Revisi Draf RKT

Setelah melakukan penysunan draf RKT Kepala MAN 1 Pekanbaru bersama tim kerja juga melakukan review dan revisi draf RKT. Sama halnya dengan RKJM, waktu yang dibutuhkan untuk mereview dan merevisi draf RKT tersebut tidak sampai satu minggu, karena untuk penyusunan rencana kerja madrasah tersebut diberi waktu maksimal satu bulan dan itu sudah mencakup dari pembentukan tim sampai dengan finalisasi.

9. Finalisasi Hasil Revisi RKT

Hal-hal yang dilakukan oleh Kepala Madrasah dan tim kerja pada saat finalisasi hasil revisi RKT ini adalah Kepala Madrasah berkumpul bersama 
ISTIGHNA, Vol. 3, No 1, Januari 2020 P-ISSN 1979-2824 E-ISSN 2655-8459

Homepage: http://e-journal.stit-islamic-village.ac.id/index.php/istighna

Nurhasimah, Nunu Mahnun, Rini Setyaningsih Penyusunan Rencana Kerja Madrasah Di Madrasah Aliyah Negeri 1 Pekanbaru

Wakil Kepala membahas kegiatan yang sudah dirumuskan dan dilakukan pengesahan.

Rencana Kerja Madrasah terdiri dari Rencana Kerja Jangka Menengah (RKJM) dan Rencana Kerja Tahunan (RKT). Rencana Kerja Jangka Menengah menjadi rencana strategis (renstra) Madrasah setelah ditandatangani oleh Kepala Madrasah dari hasil finalisasi RKJM. Sedangkan rencana kerja tahunan (RKT) menjadi Rencana Kegiatan Anggaran Madrasah (RKAM) setelah Kepala Madrasah menandatangani hasil finalisasi dari RKT.

\section{E. SIMPULAN}

Berdasarkan analisis data, maka dapat disimpulkan bahwa Kepala Madrasah Aliyah Negeri 1 Pekanbaru, sudah melakukan sistematika penyusunan Rencana Kerja Madrasah dengan mengikuti petunjuk teknis yang ada. Penyusunan Rencana Kerja Madrasah tersebut dilakukan dengan cara: 1. Pembentukan tim kerja dengan melibatkan Kepala Tata Usaha, Wakil Kepala Madrasah dan Komite Madrasah; 2. Memberikan arahan tentang penyusunan Rencana Kerja Madrasah seperti dasar-dasar penyusunan, tujuan dan anggaran yang dibutuhkan dalam penyusunan rencana kerja madrasah; 3. Menyusun rencana kegiatan seperti uraian kegiatan yang akan dilaksanakan, pelaksananya, dan juga hasil yang diharapkan; 4.Menyusun draf Rencana Kerja Jangka Menengah dengan mengidentifikasi tantangan nyata dan membuat program kerja; 5. Review dan revisi draf Rencana Kerja Jangka Menengah; 6. Finalisasi hasil revisi Rencana Kerja Jangka Menengah; 7. Penandatanganan hasil finalisasi Rencana Kerja Jangka Menengah menjadi rencana strategis Madrasah; 8. Menyusun draf Rencana Kerja Tahunan; 9. Review dan revisi draf Rencana Kerja Tahunan; 10. Finalisasi hasil revisi Rencana Kerja Tahunan; 11. Penandatanganan hasil finalisasi Rencana Kerja Tahunan menjadi Rencana Kegiatan dan Anggaran Madrasah.

\section{REFERENSI}

Afrizal, Metode Penelitian Kualitatif, Jakarta: PT Raja Grafindo Persada, 2015

Akdon, Strategic Management For Educational Management, Bandung: Alfabeta, 2009. 
ISTIGHNA, Vol. 3, No 1, Januari 2020 P-ISSN 1979-2824 E-ISSN 2655-8459

Homepage: http://e-journal.stit-islamic-village.ac.id/index.php/istighna

Nurhasimah, Nunu Mahnun, Rini Setyaningsih Penyusunan Rencana Kerja Madrasah Di Madrasah Aliyah Negeri 1 Pekanbaru

Bungin, Burhan, Metodologi Penelitian Kualitatif Aktualisasi Metodologis Ke arah Ragam Varian Kontemporer, Jakarta: Rajawali Pers, 2010.

Bugin, Burhan, Metodologi Penelitian Kuantitatif, Jakarta; Prenada Media Grup, 2010.

Calam, Ahmad dan Qurniati, Amnah, Merumuskan Visi dan Misi Lembaga Pendidikan, Jurnal SAINTIKOM, Vol. 15, No. 1, Januari 2016.

Direktorat, Juknis Penyusunan Rencana Kerja SMA, 2010.

Kementerian Pendidikan dan Kebudayaan Republik Indonesia, Badan Pengembangan dan Pembinaan Bahasa, 2016.

Muhaimin, dkk., Manajemen Pendidikan (Aplikasinya dalam Penyusunan Rencana Pengembangan Sekolah/Madrasah, Jakarta: Kencana Prenada Media Group, 2011.

Mutohar, Prim Masrokan, Manajemen Mutu Sekolah: Strategi Peningkatan Mutu dan Daya Saing Lembaga Pendidikan Islam, Jogjakarta: Ar-Ruzz Media, 2013.

Putra, Nusa, Metode Penelitian Kualitatif Manajemen, Jakarta: PT Raja Grafindo Persada, 2013.

Raihani, Kepemimpinan Sekolah Transformatif, Yogyakarta: PT. LkiS Printing Cemerlang, 2010.

Rohiat, Manajemen Sekolah: Teori Dasar dan Praktik, Bandung: PT Refika Aditama, 2012.

Sani, Ridwan Abdullah, dkk., Penjaminan Mutu Sekolah, Jakarta: PT Bumi Aksara, 2015.

Salahuddin, Marwan, Reposisi dan Eksistensi Madrasah Salafiyah di Era Global, Jurnal Pendidikan, Vol. 11, No. 2, Desember 2013. 
ISTIGHNA, Vol. 3, No 1, Januari 2020 P-ISSN 1979-2824 E-ISSN 2655-8459

Homepage: http://e-journal.stit-islamic-village.ac.id/index.php/istighna

Nurhasimah, Nunu Mahnun, Rini Setyaningsih

Penyusunan Rencana Kerja Madrasah Di Madrasah Aliyah Negeri 1 Pekanbaru

Sokhibi, Peningkatan Kemampuan Kepala Madrasah dalam Menyusun

Rencana Kerja Madrasah melalui Workshop KKMI Kecamatan Adiwerna, Jurnal Pendidikan, Vol. 8, No. 1, Maret 2018.

Sugiyono, Metode Penelitian Kuantitatif Kualitatif dan $R \& B$, Bandung: Alfabeta, 2009.

Sukmadinata, Nana Syaodih, Metode Penelitian Pendidikan, Bandung: Remaja Rosdakarya, 2001.

Suparlan, Manajemen Berbasis Sekolah dari Teori Sampai dengan Praktik, Jakarta: PT Bumi Aksara, 2013. 